\title{
Transparency as competitive advantage of innovation driven companies
}

\author{
Alona Zakutniaia \\ Assistant of the Accounting and Taxation Department, Education and Research Institute for Business \\ Technologies “UAB”, Sumy State University, Ukraine
}

\section{Arsen Hayriyan}

Ph.D. Student, Yerevan State University, Faculty of Economics and Management, Chair of Management and Business, Armenia

(C) The Authors, 2017. This article is published with open access at ARMG Publishing.

\begin{abstract}
Innovation is considered as one of features the companies' success, it is regarded as the basic element to reach customer satisfaction and realize their desires. To compete and win in today's global economy, innovation driven companies should go outside their own production cycle and become much more open. As a result, transparency became the main competitive advantage. This study aimed to identify the impact of transparency on the competitive advantage of innovation driven companies. Firstly, the article deals with the theoretical and methodological interpretation of the economic essence of the categories of "competition" and "competitiveness". The basic aspects of the categories under investigation are illustrated. Secondly, approaches to the definition of transparency and its main characteristics are analyzed in the study. Thirdly, the study investigates the features of communication policy and procedure of information disclosure by innovation driven companies.
\end{abstract}

Keywords: transparency, disclosure, competition, competitiveness, innovation, innovation driven companies.

JEL Classification: G00, F20.

\section{Introduction}

The world economic environment is characterized by rapid changes in all frameworks, especially the technological sides which become the most important discussion axise that affects the economic company's strategies. Under this new atmosphere that features the external and internal company's environment, it becomes necessary for company to fit itself in these changes to maintain its market place, and face with aggressive competition in such an open world market. Under such a situation, companies are imposed to carry out research and development in all fields through innovation and creativity regarding their methods that include management process, product, marketing, etc., to find out innovation ideas which distinguish the company from others and give it an efficient competitiveness. To compete and win in today's global economy, innovation driven companies should find ways to create and develop products and services faster than ever before. Going outside their own production cycle has become a widely accepted and applied strategy for companies. Most of them have become much more open and transparency became the main competitive advantage of innovation driven companies.

Experts and scientists pay more and more attention to the question of company's transparency. They realized that openness and permanent connection with society and market participants lay down reliable basis for effective business conducting. The experience of the USA, Sweden, the UK and Eurozone companies is valuable in this context. These companies use communication channels with the fin ancial markets to improve competitiveness level. Experts of business, international financial organizations and scientists constantly emphasize the necessity of increasing the level of companies' transparency. This fact also concerns the evidence of their social responsibility. Considerable contributions to investigate the problem were made by the following scientists: Vecchio S.D., Thompson C., Galindo G., Trott P., Hartmann W., Heald D. Nevertheless, there is no accord in the scientific literature regarding the link between innovations, competitiveness and transparency. Also, only a few studies analyses this relationship empirically. Thus, the aim of this paper is to investigate a theoretical analyze of transparency as a factor of innovation driven companies competitiveness. 


\section{Theoretical approaches to the concepts of "competition" and "competitiveness"}

Innovation and competition are complex phenomena. The importance of their relationship lies, on one side, in the uncontested proposition that sees innovation as the engine of growth (Schumpeter, 1942; Romer, 1990; Grossman \& Helpman, 1991). On the other side, the Schumpeterian proposition sees competition as one of the crucial determinants of innovative activity.

The problem of competition is traditional for economic theory. Nowadays, a great number of interpretations of the word "competition" exists. Economics includes three conceptual approaches to this term depending on the origin of the market and business entity interaction.

The first one is behavioral. Adam Smith (is known as the father of Economics) laid the foundations of market competition. He argued that every economically active person is self-interested but satisfying their interests, people are working for the benefit of society. Economic progress is achieved by division of labor, its cooperation and competitiveness and desire to get ahead of other economic agents. The net result of this competitiveness is a productivity growth that together with the division of labor provides economic development (Smith, 1759). The expand theory of free competition was developed by Karl Marx. He described the mechanisms of intra and inter-industry competition. The result of the competition, according to Marx, is the establishment of uniform price and profit margin (Marx, 1867). M. Porter emphasizes that the business entities' are motivated to provide competitiveness at the market. This approach lies in the consumers' capital thought - the maximum satisfying of their needs (Porter, 2005).

On the other hand, there is a multitude of studies based on the structural approach to the term "competition". For example, P. Sraffa concluded that the impersonal market mechanism does not depend on the activities of certain individuals and business entities. Author avers that only the market structure and the conditions of its functioning are of primer importance (Sraffa, 1926). J. Robinson was the first to demonstrate that competition is a mechanism of social production regulation which leads to interbranch migration of productive factors (Robinson, 1933). E. Chemberlain points out that the competitive market could be marked with numerous buyers of similar products. The volume of sales within such a market is so small that it is not able to influence the product price (Chemberlain, 1933).

Y. Schumpeter and F. Hayek are the representatives of a functional approach. Y. Schumpeter in his study identifies that competition is a factor of economic growth which is the result of business entities' being oriented on the introduction of innovative development strategies (Schumpeter, 1909). F. Hayek notes that the business entities should reduce expenses on production and offer their consumers new products for satisfying the growing demand to achieve competition at the market (Hayek, 1948).

There is a great number of studies of modern economists, they do not consider competition as a process of struggle and rivalry, but rather as a process of economic interaction between the business entities under certain conditions in certain situation. That is why some terminological confusion arises on the level of notional perception. Thus, there are following definitions of competition in modern economic literature:

$>$ economic process of interaction, relationship and struggle between the acting ones on market firms to provide better opportunities for their products on the market, meet different customers' needs and get the highest possible profit (Mokiy, 2010);

$>$ a contest between producers for the most profitable investments segments, markets and raw materials (Klimenko, 2006);

$>$ the process of managing competitive advantages by economic entities for achieving their goals in the rivalry with other competitors; the process of satisfying objective and subjective demands within the law or in vivo (Fatkhutdinov, 2005);

$>$ product competitiveness is the bases of any competition. It is a system of economic, managerial, technical, normative, legal, distributional and ecological factors, which in turn provide a high quality of a product and demand for it at the market in the process of interaction (Kopystko, 2010).

As a result of literature review, we can make a conclusion about the availability of plethora of theoretical studies identifying economic competition. In the context of our study, we consider that it is appropriate to distinguish the following features of the competition: it functions in the market; it is the principle method of economy; it is marked with the economic processes of interaction, interconnection and contest between the economic entities; it should contain a legal nature of competitive rivalry; it may occur on different system 
levels (micro-, meso-, macro-, megalevels); it is an indicator of economic growth, since it introduce innovative development strategies to the economic entities; it encourages the producers to look for their competitive advantages and improve them further on; it allows a few producers to score necessary results at a time.

It is obvious that all enterprises are eager to satisfy the demands of their consumers to full extent. For this reason they have to achieve some competitive advantages. The ability to create, support and develop the competitive advantages is characterized by the notion of "competitiveness".

To get more deep understanding of the term "competitiveness", a number of empirical and theoretical studies were analyzed. Scholars who do attempt to define "competitiveness", offer a wide variety of definitions: ability to stand competition and resist the competitors (Klimenko, 2006); stable opportunity to meet the specific needs of customers better than competitors, and thus successfully sell products with acceptable financial results for producers (Kharchenko, 2003); real and potential possibility for businesses in the existing conditions to design, produce and sell goods to consumers with more attractive price and non-price characteristics than the products of the competitors (Alder, 2010); ability of the product or enterprise to satisfy a specific need in comparison with similar objects on the market, it determines the ability of an object to withstand competition from similar objects on the market (Experts of the International Marketing Group (Boone, 2008).

There is a variety of competitiveness factors and their classifications in economic literature. We consider that it is appropriate to group factors according to three levels: microeconomic, macroeconomic and international in the context of our study. The first one is the micro-level. It is logical to group factors in this level according to the criteria of their belonging to industrial structures: technological, labor, organizational, informational. The second level - macroeconomic or the level of the national economy. The third level is an international economic competition. It is necessary to distinguish the following factors affecting the competitiveness of companies: customs policy, tariff policy, exchange rate, global interest rate and others.

It is worth noting that a mechanism of conducting business has undergone a dramatic transformation during the last two decades. Traditionally, firms used to produce standardized products, have a linear form of management and conveyor system of production. The predominant form of competitive strategy was cost reduction and price competition. But nowadays most firms have become innovative. The main features of innovative business are:

$>$ strategic orientation. The main benefit behind such an approach is that strategic orientation is never isolated from any aspect of the organization. It links the customer, competitor and the product approaches together to define an environment of operation of the company. So, adopting strategic orientation, the company allways considers these important business aspects;

$>$ innovation activity of the company is a continuous social process, whole team involved to the process of solving problems;

$>$ flexible production process and ability to maintain a competitive advantage constantly. It requires continuous training of all company employees engaged in various activities. Herein lies a social nature of innovation (Angrist, 2006).

In order to compete and win in today's global economy, innovation driven companies should find ways to create and develop products and services faster than ever before. Going outside their own production cycle has become a widely accepted and applied strategy of companies. Enterprises moving away from closed information system to open source systems; from domestic sourcing to global sourcing; from specialization to conglomeration; from deregulation to new forms of regulation; from closed business models to collaborative models; from Western-based business environment to multiregional rules setting. It is obviously, that mechanism of conducting business of innovation driven companies has undergone a dramatic transformation (Del Vecchio, 2010). Most of them have become much more open and transparency became the main competitive advantage of innovation driven companies.

\section{Transparency: a conceptual framework}

Term "transparency" (derived from English word "transparent" and Latin "trans" - transparency, visibility, clarity) is used in the scientific literature to indicate a state of complete awareness and information disclosure about particular object or process (Chub, 2008). 
Based on the analysis of relevant economic literature, we have found out the absence of common approach to the interpretation of the term "transparency". Scholars, who do attempt to define "transparency", offer a wide variety of definitions, usually to suit the distinct purpose of their work. Definitions run from minimal to multiple meanings. It is appropriate to analyze the following approaches in more details:

$>$ transparency relates to information flow (Stiglitz, 2000);

$>$ system of relations concerning of information disclosure and its use (Khubiiev, 2009);

$>$ availability, completeness and accuracy of information (Litovskikh, 2006);

$>$ availability, completeness, accuracy, timeliness and clarity of information (Melnyk, 2010).

In our opinion, the first approach is not grounded enough, because it is impossible to identify terms "transparency" and "information". Transparency can be also examined using a system approach (in a legal field) as a system of relations. Supporters of the third approach consider that transparency is determined by the availability, completeness and accuracy of information. In our opinion, these are characteristic features of openness, defined as a degree of disclosure. However, it is possible to publish information that is unclear for the public. In this case term "transparency" is used. Supporters of the fourth approach provide the most comprehensive and wide definition of it. Despite the above-mentioned differences in defining the nature of transparency, all scientists share the opinion that the main feature of any process transparency is information disclosure (see Figure 1 in Appendix).

Scientists identify four main characteristics of transparency, which include:

$>$ accessibility of information - provision of information in open access or on the first request;

$>$ completeness of information coverage - provision of sufficient volume of information to explain past and future actions of a central bank;

$>$ timeliness - information should be provided with a minimum delay;

$>$ integrity of information - tools and channels of information policy should be consistent and coordinated with each other (Migus, 2013; Michenera \& Berschb, 2013).

We propose to add an important characteristic - quality of provided information. No matter how often company publishes information, if it is confusing or useless. Also the presence of "information intermediaries" was ignored in scientific literature analyzed. The role of information intermediaries (variety of media: TV, radio, periodicals, etc.) is to transfer information from company to consumers.

\section{Toolkit of transparency supporting mechanism in innovation driven companies'}

Transparency is a form of coordination of private and public interests. The company is interested in obtaining an effective cooperation with stakeholders: investors, consumers, state. Counter interests of stakeholders lie in getting quality goods and services, income - for investors, loyalty - for government. Transparency is a quality characteristic of the enterprise, including: financial, goal, social, legal, technological openness (Heald, 2006).

Financial transparency is crucial to organization's stakeholders. Sharing important financial information with the general public is a great way to breed trust and loyalty. And that sense of trust between a company and its stakeholders is the key to growth and future success. For companies, which are the pioneers in innovations, being financially transparent can attract more investors, as it gives interested investors and shareholders the proof of future potential. Additionally, being open and honest about a company's financial situation with employees can help employees to see the results of their work efforts (Bushman, 2001).

Goal transparency means that the company's mission should be opened, stakeholders should understand what the company does at present, where it sees itself in the future, and how it's going to get there. We' $\mathrm{d}$ like to add that it's not enough to have the mission and vision stated on the company website, never to be seen or heard from again by employees or customers. The lacking knowledge or understanding a company's goals means the adsence of public recognition. Why it matters: regularly communicating company have goals which are critical to employee success. Employees who understand where their company is going and how it's going to get there can better align their individual work goals with those ones of the company and contribute to overall success (Stiglitz, 2000).

Social transparency provides transparency of social programs of the company, programs of human development, systems of stimulation and motivation. Also, it includes payroll transparency that is gaining traction 
within the modern workplace. Unfortunately, some companies aren't ready to embrace this level of transparency (Heald, 2006). Payroll transparency is a bold move, but can single-handedly transform the workplace. Companies that do divulge payroll information have a huge competitive advantage when it comes to attracting job seekers and retaining employees (Heald, 2006).

Legal transparency means documents transparency (starting with the establishment of the company, formation of management, corporate relationships with customers and employees, relations with public authorities)

Technological transparency is especially important for innovative companies. Companies need to combine their internal and external technological developments to produce a successful innovation that creates added values for the firm. Chesbrough contrasts a supposed closed innovation followed by some firms with an open innovation, which would be a desirable achievement. Chesbrough (2003) presents six principles of innovation, so-called "closed innovation", countering them with the principles of so-called "open innovation" (see Figure 2 in Appendix). As a result of literature review, we can make a conclusion about the availability of two main problem of technological transparency. The first one is the flight of knowledge. Transparency favours information share, but this openness can lead to the flight of sensitive knowledge, both commercial and technological. The challenge proposed is how to strike a balance between an exchange of knowledge that is enough to develop R\&D and yet remain in control of these flows (Trott \& Hartman, 2009). The second problem relates to the opening the flows of knowledge and learning with respect to the global economy, which led firms like Procter \& Gamble, and Philips to establish internal frontiers with limits on the free flow of information between their departments (Meer, 2007). The third problem concerns the strong influence of market and customers' needs as sources of innovation in global economy (Caraça, 2009). These are critical factors to product, process, organizational and market innovation. Chesbrough's (2003) view ignores this reality.

For companies of post-Soviet countries it is typical to publish only financial reports, corporate social responsibility reports and audit reports. All other important aspects of company's activity remain hidden. To make investment decision, investors need accessible, regular and reliable data. In this context the list of indicators required for disclosure was developed (see Figure 3 in Appendix).

Information required for disclosure was grouped as follows:

$>$ mandatory information (publication regulated by law or regulations);

$>$ important information (publication is not regulated, but this information has a significant impact on management decisions);

$>$ information recommended to disclose (it is important to respect the principles of essentiality and economy while adopting decision about information disclosure).

It is obviously that financial statements belong to mandatory information, but the last economic crisis showed that the financial statements have lost its significance. Investors do not trust the possibility to obtain objective information about the situation in the company only from financial statements. That's why, in order to increase usefulness and transparency of information disclosed by innovative enterprises, it is necessary to expand reporting structure with following reports environmental report, corporate social responsibility report, strategy report.

Requirements relating to disclosure should not lead to an excessive administrative burden or cause unnecessary costs. Companies should not disclose information that might jeopardize its competitive position, except when such disclosure is necessary for investment decisions. In this context a decision making algorithm was developed (see Figure 4 in Appendix).

\section{Conclusions}

Competition is the most effective mechanism for regulating the market processes, which provides economic freedom undertakings and encourages them to increase their competitiveness. Theoretical base for determining competitiveness of enterprise was analyzed. Peculiarities, role and place of competition and competitiveness in the market environment were determinant. There is a variety of competitiveness factors and their classifications in economic literature. In this paper factors were grouped according to three levels: microeconomic, macroeconomic and international. 
Mechanism of conducting business has undergone a dramatic transformation during the last two decades. Nowadays most firms have become innovative. The main features of innovative business were highlighted: strategic orientation, social nature of innovation, flexible production process and ability to maintain a competitive advantage constantly. Companies become much more open and transparency became the main competitive advantage of innovation driven companies.

Transparency is a form of coordination of private and public interests. The company is interested in obtaining the effective cooperation with stakeholders: investors, consumers, state. The review of theoretical literature on transparency and relevant empirical findings was presented in the article. The main characteristics of transparency were analyzed in the article. The authors offer two additional characteristics - the quality of the information provided and the effectiveness of information intermediaries.

The main components of transparency were analyzed (financial, goal, social, legal, technological openness). Technological transparency is especially important for innovative companies. Companies need to combine their internal and external technological developments to produce a successful innovation that creates added values for the firm. Chesbrough's six principles of open innovation, show how they are based on a false dichotomy that opposes necessarily closed innovation to open innovation, were examined. It was established that for companies of post-soviet countries, it is typical to publish in complete list of reports. In this context list of reports required for disclosure was developed. It should be mentioned that requirements relating to disclosure should not cause unnecessary costs, that's why decision making algorithm (whether the information should be disclosed) was developed.

\section{References}

1. Alder, S. (2010). Competition and innovation: does the distance to the technology frontier matter? University of Zürich, Institute for Empirical Research in Economics, Working Paper No. 493.

2. Angrist, M., and R. Cook-Deegan (2006). Who owns the genome? The New Atlantis. A Journal of Technology and Society, pp. 87-96.

3. Boone, J. (2008a). A new way to measure competition, Economic Journal, 118(5321); 1245-1261.

4. Bushman, R., Smith, A. (2001). Financial Accounting Information and Corporate Governance. Journal of Accounting and Economics, 1-3, 237-333.

5. Caraça, J.M.G., Lundvall, B.A., Mendonça, S. (2009). The changing role of science in the innovation process: from Queen to Cinderella? Technological Forecasting and Social Change, 76(6), Retrieved from: http://dx.doi.org/10.1016/j.techfore.2008.08.003. Accessed 25 February 2017.

6. Chamberlin, E.H. (1933). The Theory of Monopolistic Competition. A Reorientation of the Theory of Value, Cambridge, MA: Harvard University Press, 8th edn.

7. Chesbrough, H. (2003). Open Innovation: The new imperative for creating and profiting from technology. Boston, MA: Harvard Business School Press.

8. Chub, O.O. (2008). Pidvyshchennia transparentnosti ukrainskykh bankiv v umovakh hlobalizatsii [Increasing the transparency of Ukrainian banks in the context of globalization]. Finansy, oblik $i$ audit, 166-174.

9. Fatkhutdinov, R.A. (2005). Management of competitiveness of the organization. 2nd ed., New York: Penguin Books.

10. Grossman, G.M., Helpman, E. (1991). Quality ladders in the theory of growth. Review of Economic Studies, 58, 43-61.

11. Hayek, F.A. (1948). The Meaning of Competition, 92-106.

12. Heald, D. (2006). Varieties of Transparency. Proceedings of the British Academy, no. 135, pp. 25-43. Retrieved from: http://www.davidheald.com/publications/Healdvarieties.pdf. Accessed 28 February 2017.

13. Kharchenko, T.B. (2003). Ensuring the competitiveness of enterprises as a means of market economic reform. Actual Problems of Economy, 2.

14. Khubiiev, R.K. Transparentnost kak faktor konkurentosposobnosty [Transparency as factor of competitiveness]. In Rossiiskoie priedprinimatielstvo. Retrieved from: http://www.creativeconomy. $\mathrm{ru} /$ articles/5305.

15. Klimenko, S.M., Dubrova, O.S., Barabas, D.O., Omelyanenko, T.V., Vakulenko, A.V. (2006). Management of competitiveness of enterprise. K.: KNEU.

16. Litovskikh, A.M. (2006). Transparency and its impact on the banking sector. Izvestiya TRTU.

17. Marx, K. (1976) [1867]. Capital (vol. 1), New York: Vintage Books. 
18. Meer, H. (2007). Open Innovation The Dutch Treat: Challenges in Thinking in Business Models. Creativity and Innovation Management. Retrieved from: http://dx.doi.org/10.1111/j.14678691.2007.00433.x.

19. Melnyk, K.K. (2010). Transparency as a necessary condition to ensure the effectiveness of central bank communication. Sumy. Problemy i perspektyvy rozvytku bankivskoi systemy Ukrainy, pp. 208-216.

20. Michenera, G., Berschb, K. (2013). Identifying transparency. Retrieved from: http://katherine.bersch. gweb.io/Michener\%20and\%20Bersch\%202013.pdf.

21. Migus, I. (2013). Transparentnist banku yak skladova mexanizmu zabezpechennya jogo ekonomichnoyi bezpeky. Biznesinform, 10 .

22. Mokiy, A.I., Vasitsiv, T.G. (2010). Strategy and processes of strengthening the spatial-structural competitiveness of region, Lviv: Liga Press.

23. Porter, M. (2005). Competition: Translation from English under ed. and preface of N. Makarov, M. Williams.

24. Ricardo, D. (1817). On the Principles of Political Economy and Taxation. 1st ed. London, John Murray. $412 \mathrm{p}$.

25. Robinson, J.V. (1933). The Economics of Imperfect Competition, London: Macmillan.

26. Romer P.M. (1990). Endogenous technological change. Journal of Political Economy, 98, 71-102

27. Schumpeter, J.A. (1909). On the concept of social value. The Quarterly Journal of Economics. Oxford University Press, 23 (2), 213-232.

28. Schumpeter, J.A. (1942). Capitalism, socialism and democracy, New York: Harper and Row.

29. Smith, A. (1982) [1759]. D.D. Raphael and A.L. Macfie, ed. The Theory of Moral Sentiments. Liberty Fund.

30. Sraffa, P. (1926). The laws of returns under competitive conditions. Economic Journal, 36 (144), 535-550

31. Stiglitz, J.E. (2000). The Contribution of the Economics of Information to Twentieth Century Economics. Retrieved from: www.uv.es/ cursegsm/ MaterialCurso/p1441_s.pdf.

32. Trott, P., Hartmann, W. (2009). Why open innovation is old wine in new bottles. International Journal of Innovation Management, 13 (4). Retrieved from: http://dx.doi.org/10.1142/s1363919609002509.

33. Vecchio, S.D., Thompson, C., Galindo, G. (2010), Trust but verify: From transparency to competitive advantage. $P w C$ View, issue 13. Retrieved from: https://www.pwc.com/us/en/view/assets/pwc-view-issue13-trust-but-verify.pdf. Accessed 28 February 2017.

\section{Appendices} Environment in which companies provides general public and markets with all relevant information on its strategy,
assessments and policy decisions as well as its reports, and does so in an open, clear and timely manner

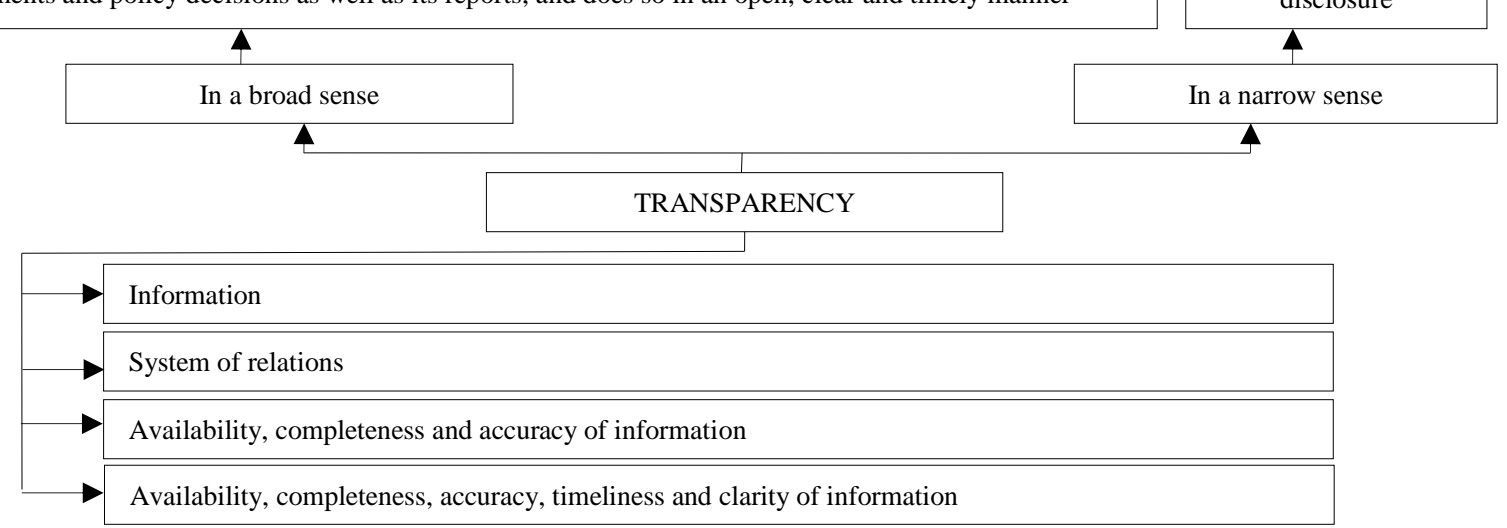

Figure 1. Approaches to defining the essence "transparency" 


\begin{tabular}{|c|} 
Open innovation \\
To profit from R\&D we have to discover, develop and \\
supply everything ourselves \\
If our organization is the first to commercialize an in- \\
novation, we will beat our rivals \\
\hline $\begin{array}{c}\text { If we create the most and best ideas in our industry, } \\
\text { we will win } \\
\text { rivals will not be able to profit from our innovative } \\
\text { ideas. }\end{array}$ \\
\hline
\end{tabular}

Closed innovation
$\begin{gathered}\text { We have to be involved in basic research to benefit from } \\ \text { it, but the discovery does not have to be ours }\end{gathered}$
$\begin{gathered}\text { If we make better use of external and internal ideas and } \\ \text { unify the knowledge created, we will win }\end{gathered}$
$\begin{gathered}\text { We should optimize the results of our organization, com- } \\ \text { burching the sale or licensing of our innovation with the }\end{gathered}$
are more efficient and economic

Figure 2. Principles of closed innovation and open innovation

Source: compiled by authors based on Chesbrough (2003)

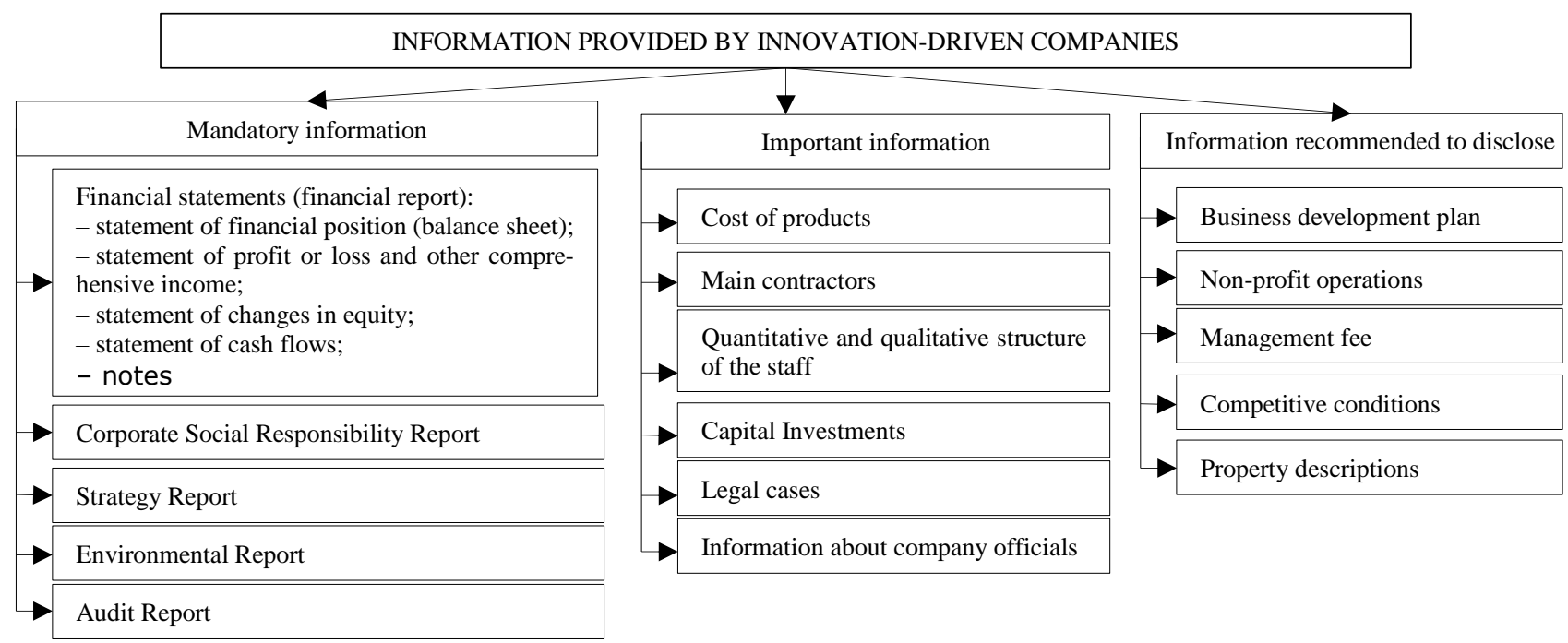

Figure 3. Information provided by innovation-driven companies

Source: compiled by authors 


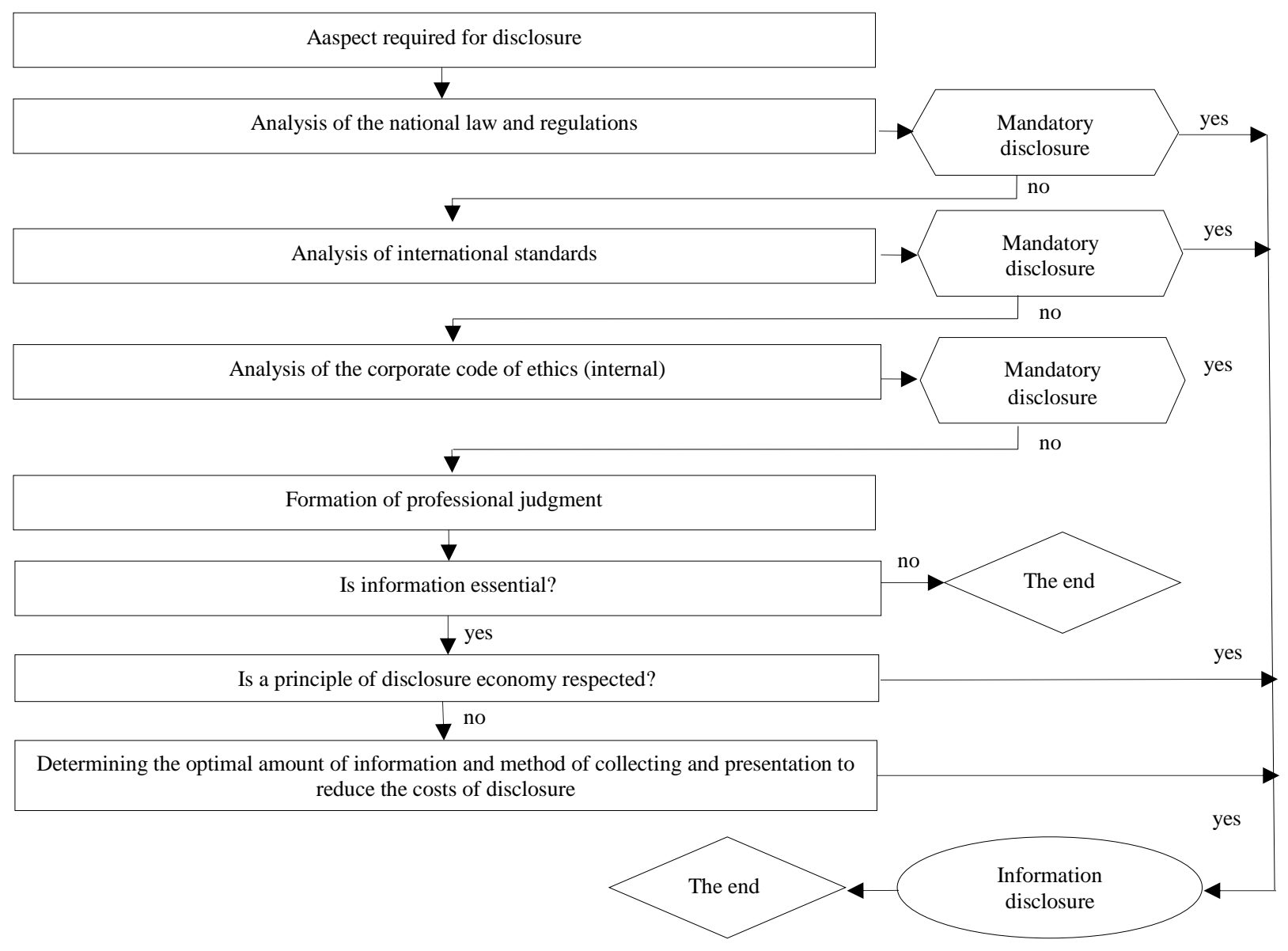

Figure 4. Decision making algorithm (is information should be disclosed?)

Source: compiled by authors 